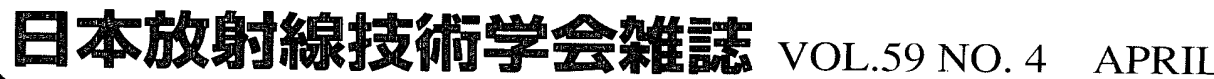
JAPANESE SOCIETY OF RADIOLOGICAL TECHNOLOGY

\section{4 月20日発行}

内容は一部变更になる場合がありますので，ご丁承ください，

教育講座一知っておくと役立つ画像診断シリーズー〈心臓領域〉

虚血性心疾患の画像情報

中村 正人

基礎講座一MRシリーズー

MRI信号の収集

基礎講座一CADシリーズー

CAD研究の方法とシステム評価

臨床技術講座

問われてくる計測の信頼性，その確保のために一JCSS制度における 放射線・放射能の標準, その供給亡利用の現状一

学術交流委員会だより

第18回(平成14年度)シ力ゴ大学短期留学報告書

小縣 裕二

第18回(平成14年度)シ力ゴ大学短期留学報告書

西出裕子

標準化小委員会だより

医用X線イメージインテンシファイア JIS Z 4721：2000 篠原 文章·他

JIRAトピックス

医療法と関連法規一医療業界から見た医療法対応一

早川登志雄

\section{論文}

原著

シミュレーションデータを用いた逐次近似画像再構成(ML-EM)

アルゴリズムの評価ーフ 種類の処理装置の比較一

松本 圭一・他

フラクタル次元解析を用いた4 Row Multi-slice Spiral CTにおける

Z方向のデー夕乗換えの複雑性評価

原 孝則・他

高速SE法T2強調画像における子宮 3 層構造描出のための

最適パラメー夕の検討

星野 佳彦·他

ノート

MR画像のSNR測定に関する基礎的検討

小倉 明夫·他

資料

当院での核医学検査施行後に発生する放射性医療廃棄物の

取扱いマニュアルの紹介

木田 哲生·他 